\title{
Body Mass Index as a Predictor of Marital Satisfaction in Married Adults
}

\author{
Azra Shaheen, Haresh Kumar, Uzma Ali, Inam Rasool
}

\section{ABSTRACT}

INTRODUCTION: Body mass index (BMI) is the important indicator of general health. Those with high $\mathrm{BMI}$ are at risk of many diseases, such as diabetes mellitus, heart diseases, high blood pressure and liver diseases. Individual feel pressure to achieve the ideal body image in order to be accepted by family, friends and their romantic partners. Women become more satisfied from their body as they feel their husbands are satisfied with their body.

OBJECTIVE: To investigate the association of body mass index and marital satisfaction in married adults.

METHODOLOGY: This cross sectional study, after approval from the Board of Advance Studies and Research (BASR), University of Karachi, was conducted from $30^{\text {th }}$ November 2014 to $30^{\text {th }}$ January 2015. Through purposive sampling, 200 married adults (100 male, 50 working and 50 non-working ladies) were selected from different organizations of Karachi. The entire sample belonged to middle socioeconomic status. After taking the consent from the participants demographic form and The Kansas Marital Satisfaction (KMS) scale were administered and responses were scored according to the procedure given in the manuals.

RESULTS: The age of the participants was between 22 to 40 years (mean $34.27 \pm 5.13$ ) with the minimum of 2 years and maximum of 20 years of marriage. Their educational level was ranging from graduation and above. The mean height of participants was 5.44 feet, weight $67.33 \mathrm{~kg}$, BMI 24.25 and mean duration of marriage was 2.5 years. Linear regression showed that the correlation between BMI and martial satisfaction is significant $(p=<.05)$ in married adults.

CONCLUSION: It is concluded that dissatisfaction with body weight negatively affects marital satisfaction.

KEY WORDS: Body mass index, marital satisfaction, Married adults

This article may be cited as: Shaheen A, Kumar H, Ali U, Rasool I. Body Mass Index as a Predictor of Marital Satisfaction in Married Adults. J Liaquat Uni Med Health Sci. 2017;16(04):228-32. doi: 10.22442/jlumhs.171640539

\section{INTRODUCTION}

Body mass index (BMI) is the important indicator of general health. Those with high BMI are at risk of many diseases, such as diabetes mellitus, heart diseases, high blood pressure and liver diseases ${ }^{1}$. On the other hand effect of body weight on marital satisfaction also receives attention in recent scholarly work. Studies indicated significant association between body weight, marital status and general health ${ }^{2-3}$. The difference between married and non married individual's perception regarding their body-image and marital relationship are the subject matter of many researchers and the finding suggested that there is a significant relationship between marital satisfaction and body-image ${ }^{4}$.

Marital satisfaction is associated with weight gain, this association has been explained by different models; health regulation model suggests that supportive and satisfied marital relationship promote health related behavior which results in weight gain that is why newly married couples are at risk of weight gain. In contrast the mating market model concluded that physical attractiveness is a significant element in the beginning of the romantic relationship or selecting partners for marriage. This pressure leads to concern about one's body size and weight $t^{5,6}$. For marriage the ideal weight differs for gender; thinness for women and muscular physique for men, moreover, to be over-weight for women and under-weight for men is disadvantageous not only for marriage but people less likely to date with them $^{7}$. Socio-cultural factors such as views of family members, friends and spouse are important predictors of developing positive and negative body image. Individual feel pressure to achieve the ideal body image in order to be accepted by family, friends and their romantic partners ${ }^{8}$. Couple frequently compare each other on the basis of physical appearance and weight as compared to comparison of abilities and work. With romantic relationship people often 
engage in weight related talk which leads to body-dissatisfaction ${ }^{9,10}$. Meltzer, et al ${ }^{3}$ showed that BMI of husband and wife is linked to marital satisfaction; husbands were more satisfied initially and wives were more satisfied over time to the extent that wives had lower BMls than their husbands. Married females tend to perceive themselves as overweight and develop feelings of inadequacy due to partner's criticisms about their weight and body shape which causes maladaptive exercises or dieting and also negatively affect their relationships. Women become more satisfied from their body as they feel their husbands are satisfied with their body ${ }^{11}$. Although review of the literature indicated the significance of body image and body mass index as a significant factor in context to marital reltionship, however available national literature is sparse and therefore this study will add considerable knowledge that to what extent these variables are related and that how body mass index predicate marital satisfaction in married adults of Karachi, Pakistan.

\section{METHODOLOGY}

\section{Participants}

The study population consisted of 200 married adults, 100 males and 100 females (50 females working and 50 non working) belonging from both; Nuclear and Joint family structures having educational level graduation and above. As there is no published data about BMI and marital satisfaction in Pakistan, sample size calculation was carried out by using correlation formula based on the correlation coefficient between BMI and marital satisfaction using 95\% confidence interval and power of $80 \%$, and it was estimated that a sample size of 100 is needed for each group. Data was selected from different organizations in Karachi through purposive sampling. The age range of the participants was 22 to 40 years with a minimum of 2 years and maximum of 20 years to marriage. They belonged to the middle socioeconomic class as per criteria defined in Household Integrated Economic Survey 2001-2002 by Pakistan Bureau of Statistics Govt of Pakistan.

\section{Materials}

\section{1) Demographic Information Form}

Demographic information form (Self developed) consisted of the participant's age, gender, education, family structure, socioeconomic status, job status, weight, height and duration of marriage.

\section{2) Body Mass Index (BMI)}

Participants were asked to provide data on their weight (in pounds) and height (in inches). To compute BMI respondent's weight first converted into kilograms and their height converted into meters, then BMI calculated by taking respondents weight in kilogram and dividing by height in meters squared.

\section{3) The Kansa Marital Satisfaction scale (KMS, Schumm 1983)}

The Kansas Marital Satisfaction (KMS) scale is short three item self-reported scale. It is designed to quickly assess marital satisfaction. Respondents required indicating their relationship satisfaction on a 7-point scale ranging from 1 (extremely dissatisfied) to 7 (extremely satisfied). KMS assess satisfaction with spouse, marriage and relationship satisfaction with spouse. It is a valid and reliable scale to differentiate between satisfied and dissatisfied spouses. It has high internal consistency Cronbach's alpha >.95.

\section{Procedure}

The research synopsis was approved by Board of Advance studies and research (BASR), University of Karachi. Informed consent from participants and permission from different organizations were taken. The researcher also addressed the matter of confidentiality and right to withdraw from the study. A sample of 200 married adults was collected through purposive sampling. The participants completed the demographic information and asked to give their height and weight in the questionnaire to compute their body mass index, then they completed The Kansas Marital Satisfaction (KMS) scale and responses were scored according to the procedure given in manuals. At the end, they were thanked for their cooperation. Descriptive statistic and linear regression were computed in order to interpret the data through SPSS.

\section{RESULTS}

Table 1-3 shows descriptive statistics, mean and standard deviation. The significant findings of linear regression presented in Table 4 and 5 .

Table 3 shows most of the married adults has educational level $\left(14^{\text {th }}\right.$ grade, $\left.40 \%\right)$, govt job $(40.5 \%)$, arrange marriage $(72 \%)$ and middle born $(32 \%)$, and they belong to both nuclear and joint family.

\section{Body mass index predicts marital satisfaction in married adults}

Body mass index and depression as study variables were included in a linear regression analysis to evaluate the contribution of Body mass index in the prediction of marital satisfaction among married adults. 
Azra Shaheen, Haresh Kumar, Uzma Ali, Inam Rasool

TABLE I: MEAN AGE, HEIGHT, WEIGHT AND DURATION OF MARRIAGE

\begin{tabular}{|l|c|r|r|}
\hline \multicolumn{1}{|c|}{ Variables } & n & \multicolumn{1}{c|}{ Mean } & \multicolumn{1}{c|}{ ISD } \\
\hline Age ( years) & 200 & 34.27 & 5.13 \\
\hline Height & 200 & 5.44 & 0.36 \\
\hline Weight(kg) & 200 & 67.33 & 11.88 \\
\hline Duration of marriage (years) & 200 & 2.5 & 1.26 \\
\hline BMl & 200 & 24.25 & 4.32 \\
\hline
\end{tabular}

TABLE II:

\begin{tabular}{|l|r|c|}
\hline \multicolumn{1}{|c|}{ Variables } & \multicolumn{1}{c|}{ (BMI) } & n (\%) \\
\hline Under weight & $>18$ & $13(6.5)$ \\
\hline Normal weight & $18-24.9$ & $102(51)$ \\
\hline Overweight & $25-29.9$ & $63(31.5)$ \\
\hline Obese & $>30$ & $22(11)$ \\
\hline
\end{tabular}

TABLE III: DESCRIPTIVE STATISTICS OF DEMOGRAPHIC INFORMATION'S OF ENTIRE SAMPLE

\begin{tabular}{|c|c|c|}
\hline Variables & Frequency & Percentage \% \\
\hline \multicolumn{3}{|l|}{ Educational level } \\
\hline Graduation $\left(14^{\text {th }}\right.$ grade $)$ & 81 & 40.5 \\
\hline Masters $\left(16^{\text {th }}\right.$ grade $)$ & 69 & 34.5 \\
\hline $\begin{array}{r}\text { Post masters (above } \\
16^{\text {th }} \text { grade) }\end{array}$ & 50 & 25 \\
\hline \multicolumn{3}{|l|}{ Family system } \\
\hline Nuclear & 93 & 46.5 \\
\hline Joint & 107 & 53.5 \\
\hline \multicolumn{3}{|l|}{ Birth order } \\
\hline $1^{\text {st }}$ born & 96 & 48 \\
\hline Middle born & 64 & 32 \\
\hline Last born & 40 & 20 \\
\hline \multicolumn{3}{|l|}{ Occupation } \\
\hline Govt. job & 81 & 40.5 \\
\hline Private job & 69 & 34.5 \\
\hline Not working & 50 & 25 \\
\hline \multicolumn{3}{|l|}{ Type of marriage } \\
\hline Arrange & 144 & 72 \\
\hline Love & 56 & 28 \\
\hline
\end{tabular}

TABLE IV: MODEL SUMMARY OF LINEAR REGRESSION ANALYSIS

\begin{tabular}{|c|c|r|r|r|r|}
\hline Predictor & $\mathbf{R}$ & $\begin{array}{c}\mathbf{R} \\
\text { Square }\end{array}$ & $\begin{array}{c}\text { Adjusted } \\
\text { R Square }\end{array}$ & $\begin{array}{c}\mathbf{F} \\
\text { change }\end{array}$ & $\begin{array}{c}\mathbf{P} \\
\text { value }\end{array}$ \\
\hline BMI & $.172^{\mathrm{a}}$ & .029 & .025 & 6.013 & .015 \\
\hline
\end{tabular}

BMI: Body mass index (constant)

Marital satisfaction (Dependent variable)

TABLE V: COEFFICIENTS

\begin{tabular}{|l|l|r|r|r|r|r|}
\hline \multirow{2}{*}{ Model } & & \multicolumn{2}{|c|}{$\begin{array}{c}\text { Un-standardized } \\
\text { coefficients }\end{array}$} & $\begin{array}{c}\text { Stan- } \\
\text { dardize } \\
\text { d coef- } \\
\text { ficients }\end{array}$ & t & P \\
\hline & & B & Std. Error & Beta & & \\
\hline 1 & Constant & 18.564 & 1.497 & & 12.401 & .000 \\
\hline & BMI & -.149 & .061 & -.172 & -2.452 & .015 \\
\hline
\end{tabular}

$P<0.001^{*}$

\section{DISCUSSION}

In the past few decades the concerns over body weight and the importance of body shapes are becoming the norm and great emphasis is placed on body image by both genders but risk is higher for women. Physical appearance, ideal body weight and shape have an important role in a spousal relationship ${ }^{12}$.

The objective of the present study was to investigate the link between body mass index and marital satisfaction in married adults and the findings suggested that body mass index was a significant predictor of relationship satisfaction in married adults. The social norms theory suggested that people who failed to achieve the ideal body weight and shape experience high level of marital dissatisfaction ${ }^{13.14}$. People with high BMI face stigmatization and prejudiced in romantic relationship, lower BMI is preferentially selected into marriage by U.S women and high BMI are less likely to marry as compare to normal weight, consequently upon difficulty in marriage, they feel less confident in attracting a partner and found to have a less satisfying marital relationship ${ }^{15}$. Women feel more pressure to achieve ideal body image because their bodies are objectified to satisfy men that is why in marital relationship women evaluate and concern about body image more, but primary purpose was to seek attention and positive view of their husband ${ }^{16}$. A study conducted on body shape dissatisfaction and weight status in Saudi Arabia found marital status as predictor for body dissatisfaction among married females furthermore perception of husband about their body contributing to women's dissatisfaction ${ }^{18}$. Similarly, results of ninety 
American couples suggested that females were more satisfied with their body weight and shape when they perceived their were satisfied ${ }^{15}$. Mokhtari and Pollock also found negative association between BMI and marital satisfaction among a sample of US women ${ }^{1}$. Dissatisfaction of body weight and shape lead to anxiety and fear of intimacy which inhibit self disclosure that affect negative spousal relationship. Sexual satisfaction is an important factor in marital satisfaction, but people with negative body image perceive their bodies unattractive and also seems to avoid self disclosure both physically and emotionally during sexual relationship which in turn lead to dissatisfied marital relationships ${ }^{18}$. Consistent with this Karamidehkordi and Roudsari studied relationship between body dissatisfaction, sexual function and marital adjustment in Iranian women, and found a significant relationship between body dissatisfaction with marital satisfaction and sexual function. The better they feel about their body weight and shape, more they are satisfied with sexual relationships ${ }^{19}$.

\section{CONCLUSION}

Our finding suggested that body mass index appears to be a predictor of marital satisfaction in married adults.

\section{REFERENCES}

1. Mokhtari M, Pollock ED. Weight, Mental Health, Income and Marital Satisfaction: Evidence from the National Longitudinal Survey of Youth. J Obes Weight Loss. 2015; 1: 001 . doi: 10.24966/ OWL-7372/1000001

2. Kiecolt-Glaser JK, Jaremka L, Andridge R, Peng J, Habash D, Fagundes CP, et al. Marital discord, past depression, and metabolic responses to high -fat meals: Interpersonal pathways to obesity. Psychoneuroendocrinology. 2015; 52: 239-50. doi: 10.1016/j.psyneuen.2014.11.018.

3. Meltzer AL, McNulty JK, Novak SA, Butler EA, Karney BR. Marriages are more satisfying when wives are thinner than their husbands. Soc Psy-ch Per Sci. 2011;2(4): 416-424. doi:10.1177/1948550610395781

4. Friedman MA, Dixon AE, Brownell KD, Whisman MA, Wilfley DE. Marital status, marital satisfaction, and body image dissatisfaction. Int $\mathrm{J}$ Eat Disord. 1999; 26(1):81-5.

5. Mata J, Frank R, Hertwig R. Higher body mass index, less exercise, but healthier eating in married adults: Nine representative surveys across Europe. Soc Sci Med. 2015; 138:119-127. doi: 10.1016/j.socscimed.2015.06.001.
6. Meltzer AL, McNulty JK, Novak S, Butler EA, Karney BR. Marital satisfaction predicts weight gain in early marriage. Health Psychol. 2013; 32 (7):824-7. doi: 10.1037/a0031593.

7. Lee C. Body Mass Index and Body Image Dysfunction as Predictors of Women Perceived Romantic Relationship Quality. 2011. Electronic Theses and Dissertations. Paper 231. University of Windsor.

8. Cash TF, Smolak L. Body image: a hand book of science, practice, and prevention. $2^{\text {nd }}$ ed. New York: The Guilford Press; 2011.

9. Bookwala J, Boyar J. Gender, excessive body weight, and psychological well-being in adulthood. Psychology of Woman Quarterly. 2008; 32(2):188 $-195$

10. Bove CF, Sobal J. Body weight relationships in early marriage. Weight relevance, weight comparisons, and weight talk. Appetite. 2011; 57 (3):729-742. doi: 10.1016/j.appet.2011.08.007.

11. Klos LA, Sobal J. Marital status and body weight, weight perception, and weight management among US adults. Eat Behav. 2013; 14(4): 500-7. doi: 10.1016/j.eatbeh.2013.07.008.

12. Pollock ED. The relationship between mental health, physical health, physical appearance and marital dissatisfaction, Master thesis of science, marriage and family therapy. University of Maryland, College park 2006.

13. Cheng, $\mathrm{H}$. Body image dissatisfaction of college women: potential risk and protective factors. Thesis doctor of philosophy. University of Missouri -Columbia. 2006.

14. Swami V, Airs N, Chouhan B, Leon M, Towell T. Are there ethnic differences in positive body image among female British undergraduates? European Psychologist 2009; 14: 288-296.

15. Markey C, Markey P. Romantic relationships and body satisfaction among young Women. J of Youth and Adolesc. 2006:35(2): 256-264.

16. Cash TF, Thériault J, Annis NM. Body image in an interpersonal context: Adult attachment, fear of intimacy and social anxiety. J Social and Clinical Psychol. 2004;23(1):89-103. doi: 10.1521/ jscp.23.1.89.26987

17. AL-Otaibi H, Nassef $S$, Raouf T. Body shape dissatisfaction, weight status and physical activity among a sample University students in Saudi Arabia. J Food and nutrition sci.2013; 4(6): 61625. doi: $10.4236 /$ fns.2013.46079.

18. Meltzer A, McNulty J. Body image and marital satisfaction; evidence for the mediating role of sexual frequency and sexual satisfaction. J Fam 
Psychol 2010; 24(2): 156-164. doi: 10.1037/ a0019063

19. Karamidehkordi A, Roudsari RL. Body image and its relationship with sexual function and marital adjustment in infertile women. Iran J Nursing Midwifery Res.2014; 19(7 Suppl 1):S51-S58.
20. Jokela M. Physical attractiveness and reproductive success in humans: Evidence from the late $20^{\text {th }}$ century United States. Evol Hum Behav. 2009; 30(5):342-50. doi: 10.1016/ j.evolhumbehav.2009.03.006

AUTHOR AFFILIATION:

Ms. Azra Shaheen

Assistant Professor

Institute of Clinical Psychology

University of Karachi

Karachi, Sindh-Pakistan.

Dr. Haresh Kumar (Corresponding Author) Assistant Professor of Psychiatry

Khairpur Medical College

Khairpur Mirs, Sindh-Pakistan.

Email: hareshmakhija@gmail.com

Dr. Uzma Ali

Associate Professor

Institute of Clinical Psychology

University of Karachi

Karachi, Sindh-Pakistan.

Prof. Inam Rasool

Institute of Psychiatry

Baqai Medical University

Karachi, Sindh-Pakistan. 